\title{
Enhancing Asia's trade: price and non-price barriers revisited
}

\author{
Prabir De*
}

\begin{abstract}
In a supply-constrained region like Asia, promoting exports has always been a challenge particularly at a time when Asia's trade has been severely affected by lack of external demand. This paper argues that price barriers have taken a new shape during the global financial crisis period which may generate differential impacts on trade flows as we proceed toward recovery. The size and shape of price barriers would be higher if NTBs, applied by the countries during the crisis period, were counted. One of the conclusions of this paper is that 'price' barrier is still more important than 'non-price' barrier in enhancing Asia's trade and integration. The higher the price barrier between countries in a pair, the less they trade. In other words, a 10 percent increase in the ad-valorem price (transport and tariff) lowered trade by 6 percent. Tariff and transport costs, each considered separately, also influence the trade flow in the same direction, to more or less the same extent. There are indications of huge domestic infrastructure bottlenecks in countries in Asia. Based on direct and indirect evidence related to trade barriers, this paper concludes that complementary trade policies focusing on price and non-price barriers have immense importance in enhancing international trade and integration in the post-crisis period.
\end{abstract}

Keywords: Trade Cost, Transportation, Asia, Regional Integration, Gravity model.

JEL codes: F1, F15, F17

Submission Date: 30/03/2010

Revision Date: 12/05/2010

Acceptance Date: 19/05/2010

* Fellow, Research and Information System for Developing Countries (RIS), India Habitat Centre, Lodhi Road, New Delhi 110 003, India, Tel. (+91-11) 24682177, Fax. (+91-11) 24682174, E-mail: prabirde@hotmail.com An earlier version of the paper was presented at the international conference on 'Trade Costs, Infrastructure and Trade Development in Asia', organized by the Leverhulme Centre for Research on Globalisation and Economic Policy (GEP), University of Nottingham, held at the Kuala Lumpur Teaching Centre, the University of Nottingham Malaysia Campus, Kuala Lumpur, 13-14 January 2010. Author is grateful to conference participants, Jay Menon and two anonymous referees of the journal for their insightful comments on the paper. Views expressed by the author are his personal. Usual disclaimers apply. 


\section{Introduction}

The world is entering a new phase amid signs of a return to positive growth in many countries. ${ }^{1}$ Some countries are poised to back in pre-crisis level growth momentum, while some are yet to recover from the slump. The recovery is proceeding at different speeds, and the result at this juncture is rather mixed.

Global trade flows contracted by a catastrophic 12 percent in 2009, the fastest pace since the Second World War. ${ }^{2}$ This latest estimate is considerably worse than the WTO's previous forecast of a 10 percent decline for last year, underlining the hefty costs of the financial crisis for the world economy. Contraction of world output has led to decline in the volume of trade. ${ }^{3}$

The ongoing global economic crisis has put enormous pressure on exporters to increase their productivity and reduce costs so as to secure their share of a shrinking global market (UNESCAP, 2009). Enormous current account deficits in the US, which have facilitated export-led growth in Asia in the past, would likely fall. ${ }^{4}$ At the same time, rapid economic growth in China and India will continue, continuing the re-orientation of trade toward Asia. Critiques argue that regional trade in such a situation will eventually rise in Asia and there is thus need for regional demand driven growth rebalancing. ${ }^{5}$ In the past, Asia's growing international and regional economic networks through the exchange of goods, services and capital has been fostered by the development and efficient uses of supporting infrastructure, both hard (physical) and soft (institutional). The importance of tariffs as barriers to trade has therefore gradually declined; however, high tariffs still exist for certain sensitive products, and there is a strong presence of non-tariff barriers (NTBs) including high transaction costs in the region. Therefore, the regional demand from a rebalancing of growth might be suboptimal if not supported by lower trade costs in Asia.

In a supply-constrained region like Asia, promoting exports has always been a challenge particularly at a time when trade has been severely affected by lack of external demand. Although the current export slowdown is a temporary phenomenon, it surely has

\footnotetext{
1 Refer, for example, IMF (2010a), which commented "The global recovery is off to a stronger start than anticipated earlier but is proceeding at different speeds in the various regions."

2 Refer, Director-General Pascal Lamy's speech to the European Policy Centre in Brussels on 24 February 2010, available at http://www.wto.org/english/news_e/sppl_e/sppl148_e.htm

3 It was estimated a collapse of US\$ 16 trillion of trade in 2008, reaching US $\$ 5.8$ trillion in the first half of 2009 compared to US\$ 8.2 trillion in the corresponding period of 2008 (cited in Government of India, 2010, p. 145)

4 Refer, Hummels (2008), according to whom it was led to major cargo imbalances across the world.

5 Refer, for example, Kawai (2009), Park (2009).
} 
some long-term trade (and regional integration) policy implications. Any slowdown in trade might influence trade costs differently across countries due to volume, price and scale effects of trade. More importantly, 'price' barriers become stronger in post-crisis periods, thus having the tendency to negate the benefits of trade liberalization initiated in the pre-crisis period, to bring the trade cost in countries to the pre-crisis level, and to encourage further external distortions. In this paper, we attempt to understand the impact of 'price' and 'non-price' barriers on Asia's trade.

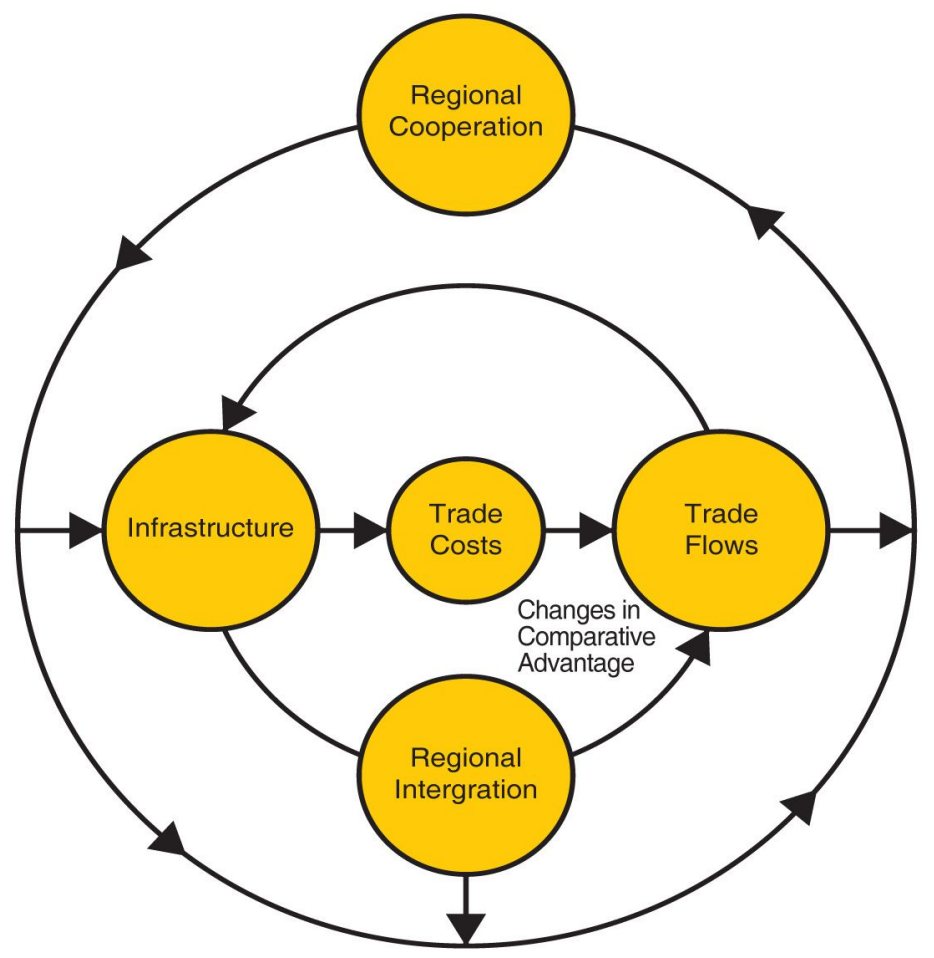

Source: Brooks (2008a)

Figure 1. Changes in Comparative Advantage

There is also another important point for which the study on trade costs is very important. Brooks (2008a) argued that as production services become increasingly fragmented and traded internationally, cooperation among the economies participating in those production networks becomes more crucial to maintain or raise an individual host country industry's competitiveness in supplying those services. Infrastructure investment that reduces trade costs facilitates regional economic integration through trade and 
investment expansion, which motivates regional cooperation, including cooperation in infrastructure development, generating a virtuous cycle. A simple depiction of the relationships, adapted from Brooks (2008a), is presented in Figure 1. The infrastructure investment (which many countries have undertaken as a stimulus package in the crisis period) may not lead to facilitate trade flows if it is not supported by lower trade costs. Countries eventually will lose their journey in gaining comparative advantages due to rises in trade costs - price and otherwise. Besides, rising trade procedures and processes would ruin trade transaction. ${ }^{6}$ Importantly, inefficient trade procedures may lead to the de facto exclusion of a country from regional and global production networks and value chains, significantly affecting that country's trade and investment prospects as well as opportunities for its enterprises to climb up the value chain. Asia's trade-supporting infrastructure therefore needs massive improvements to maintain the competitiveness of existing production networks and widen their benefits, notably to inland parts of Asia (Brooks, 2009; ADB-ADBI, 2009).7

The rest of the paper is organized as follows. Section 2 presents the motivation of the study. Data and methodology are introduced in Section 3. The issue of which barriers are important: price or non-price, is addressed in Section 4. Finally, conclusions are made in Section 5.

\section{Why Revisit Price and Non-price Barriers to Trade}

The set of literature examining the direct evidences on border costs shows that tariff barriers are now low in most countries. ${ }^{8}$ On average (trade-weighted), they are less than 5 percent for rich countries and, with a few exceptions, between 10 and 20 percent for developing countries. ${ }^{9}$ While the world has experienced a drastic fall in tariffs over the last two decades, several barriers that penalize trade remain. Some are referred to as "soft" barriers, others as "hard" barriers. While "soft" barriers are addressed through trade and business facilitation, and institutional measures, "hard" barriers which are considered to comprise physical or infrastructure barriers, are addressed through transport facilitation measures. The costs arising from these two broad types of trade barriers can be grouped together and referred to collectively as trade costs.

\footnotetext{
${ }^{6}$ Although estimates vary widely, it is generally found that trade transaction costs (TTC) associated with import and export procedures (excluding tariffs) amount to 7 to 10 percent of the value of goods traded (Engman, 2009).

7 The whole set of empirical studies show that Asia has been suffering more due to high costs of transportation, and countries in Asia with better trade-supporting infrastructure trade more than those which lack in it (Brooks and Hummels, 2009; Brooks and Menon, 2008).

8 See, for example, Anderson and van Wincoop (2004).

9 Refer, Anderson and van Wincoop (2004). WTO (2006a), WTO (2007), and ITC (2007)
} 
Trade costs are often cited as an important determinant of trade volume. High trade costs create obstacles to trade and impede the realization of gains from trade liberalizatio n. ${ }^{10}$ Most of the studies on trade costs show that integration is the result of reduced costs of transportation in particular and other infrastructure services in general. Supply constraints are the primary factors that have limited the capacity of many developing and lesser developed countries to exploit the trade opportunities arising from trade liberalization. An optimal gain from trade, therefore, depends not only on tariff liberalization but also on the quality of infrastructure and related services associated with cross-border trading.

Trade costs have large welfare implications. Current policy-related costs are often valued at more than 10 per cent of national income (Anderson and van Wincoop, 2002). Obstfeld and Rogoff (2000) commented that all the major puzzles of international macroeconomics hang on trade costs. Some studies, for example Francois et al. (2005), have estimated that for each 1 percent reduction of trade transaction costs, world income could increase by S\$ 30 to $\$ 40$ billion USD. 11 The gains from streamlining customs procedures have exceeded those resulting from trade liberalization, such as tariff reduction. An APEC Study in 2002 indicated that gains from effective trade facilitation accounted for about 0.26 percent of real gross domestic product (GDP) of APEC members (about $\$ 45$ billion USD) for the year 2006, while the gains from trade liberalization for 2006 would be 0.14 percent of real GDP (about $\$ 23$ billion USD). ${ }^{12}$ The same study also indicated that efforts to achieve APEC's commitment to reduce trade-related transaction costs by 5 percent by 2006 could raise APEC's GDP by 0.9 percent (\$ 154 billion USD a year in 1997 prices) and lift real consumption to 5.5 percent above what it would otherwise be. Wilson and others (2002) estimated that raising trade facilitation performance across the region to half the level of the APEC average could result in a 10 percent increase-worth roughly $\$$ 280 billion USD - in intra-APEC exports.

The cost of international trade is a crucial determinant of a country's trade competitiveness. The doubling of a country's transport costs leads to a drop in its trade of 80 per cent or even higher (Limão and Venables 2001). In many cases, the effective rate of protection provided by the international transport costs ${ }^{13}$ was found to be higher than that provided by tariffs.

10 A growing amount of literature has documented the impact of trade costs on the volume of trade (see, Duval 2007; Duval and Uttapam, 2009). Seminal studies carried out on this topic in recent years include: Hummels (1999, 2007), Limão and Venables (2001), Anderson and van Wincoop (2004), and Brooks (2008).

11 See also APEC (2002), Walkenhorst and Yasui (2003).

12 Refer, APEC (2002).

13 In the case of a cross-border shipment of goods, transport costs comprise two major elements: (a) international transport costs, which include costs associated with the shipment of goods from one country to another; and (b) inland (domestic) transport costs, which include the costs of inland transportation of merchandise in both exporting and importing countries. 
Thus, international transportation costs represent a greater barrier than tariffs, and, in turn, a more binding constraint to greater participation in international trade. ${ }^{14}$ However, progress has been made in reducing international transport costs. Among the Asian countries, international transport costs vary widely from less than 5 percent for most of the Southeast Asian countries to over 20 percent for Bhutan (UNESCAP, 2009). The most progress was achieved in Southeast Asia, the only subregion to outperform the world average (UNESCAP, 2009).

While calculating the transport costs, the difference between import price (cif) and export price $(f o b)$ has been used, capturing broadly defined international transport costs. A progressive reduction in the cif to fob price gap can be interpreted as an increase in international trade and transport efficiency, particularly if this is achieved through improved port and related international transport infrastructure and services available in the exporting country. But, slowdown in import demand in the US in the crisis period has apparently made the Asian exports to the US more expensive in relative terms (Figure 1). Changes in slope (pre-crisis negative to post-crisis positive) and the corresponding intercepts in Figure 1(b) confirm this.

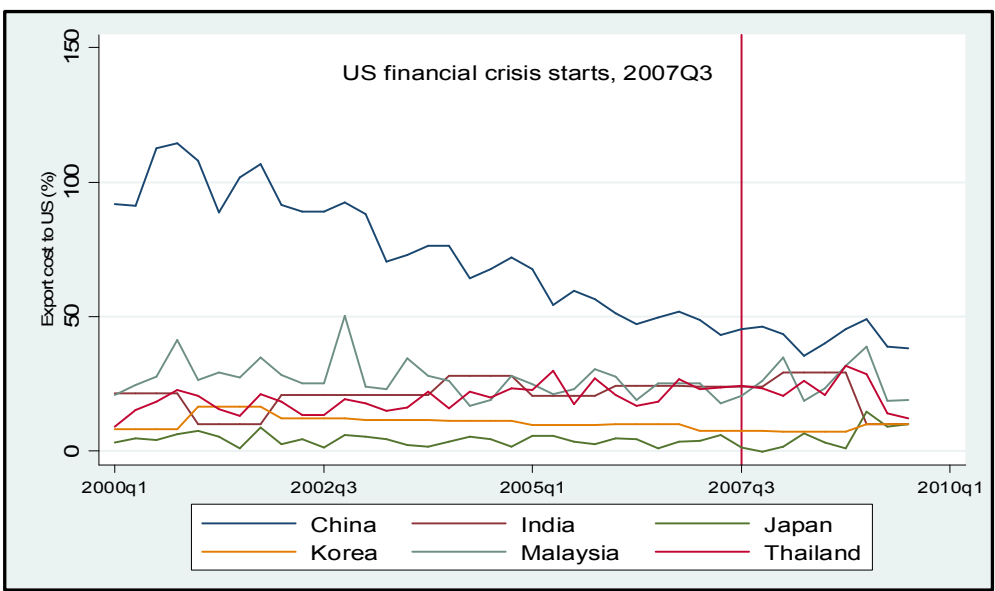

Note: *For exports to US

Source: Quarterly data collected from IMF (2010b)

Figure 1(a). Advalorem Trade Costs*

14 According to the World Bank (2001), for 168 of 216 trading partners of the United States of America, transport cost barriers outweighed tariff barriers. For the majority of countries in sub-Saharan Africa, Latin America and the Caribbean, and a large part of Asia, the transport cost incidence for exports is five times higher than the tariff cost incidence. 


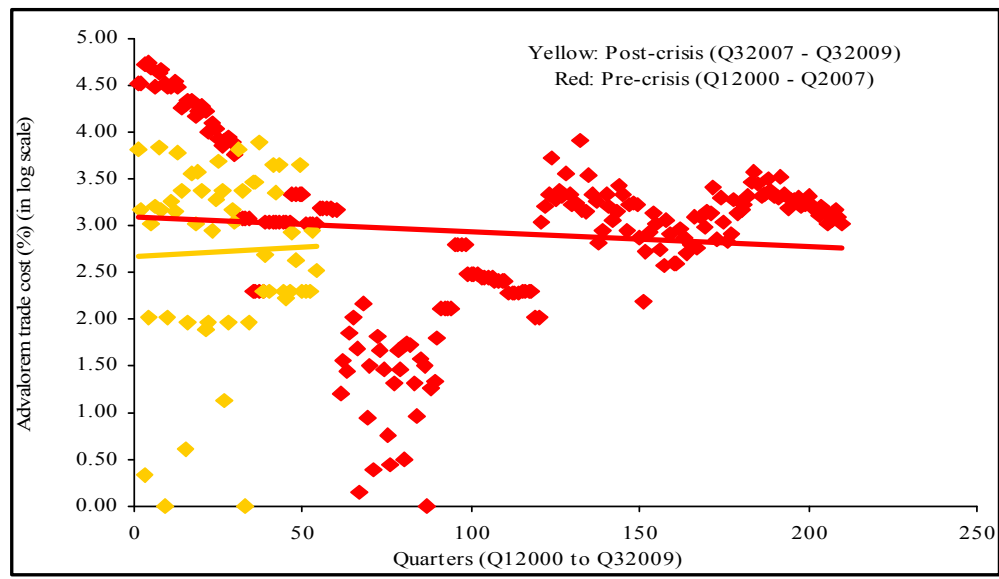

Note: Advalorem trade costs $=[(\text { Import price }- \text { Export price }) / \text { Export price }]^{*} 100$, where cif and fob prices represent import and export prices of trade, respectively, taken at current price. Figure 1(b) considers 6 Asian countries of Figure 1(a).

Source: Quarterly data collected from IMF (2010b)

Figure 1(b). Global Crisis Making Asian Exports to US Expensive

Therefore, the foregoing analysis clearly shows that the price barriers have now taken a new shape, and their impact on trade flows is thus unavoidable. The size and shape of price barriers would be higher if NTBs, applied by the countries in the crisis years, were counted. Therefore, complementary trade policies focusing on price and non-price barriers have immense importance in enhancing international trade and integration.

In view of the above, the purpose of this study, which is based on direct and indirect evidences related to trade barriers, is to explore responses to these questions, thereby enhancing the understanding of the role trade costs play in enhancing Asia's trade competitiveness. Such an understanding could facilitate initiatives to integrate production across Asia as well as those aimed at promoting deeper trade integration in the region.

\section{Data and Methodology}

We attempt to assess the impact of trade costs (barriers to trade) on trade flows in the context of six Asian countries, namely, China, India, Japan, Malaysia, Korea and Thailand. In other words, we test how changes in trade cost components affect import demand. We estimate the impact of transport costs and other barriers on regional trade and competitiveness, controlling for other variables, in the framework of a gravity model. We deal with those barriers (components of trade costs) which are both imposed by price (e.g. freight and tariff rates) and non-price (infrastructure) factors. 
Of all the components of trade transaction, transport cost has been studied the most extensively. Generally, there are two approaches to transport modeling in trade: (a) one in which transport is modeled implicitly with the traded goods; 15 and (b) one which involves explicit transport sector modeling. The former relates to price factors, while the latter deals predominantly with non-price factors. As trade costs are heavily dependent on both types of factors, we explore both approaches here.

Here, a world of $\mathrm{N}$ countries and a continuum of differentiated goods are considered. It is assumed that countries specialize in a range of goods and that consumers have constant elasticity of substitution (CES) preferences. ${ }^{16}$ Following Anderson and van Wincoop (2003 and 2004), a theoretically consistent gravity model is then applied for exports between country $i$ and country $j$ in sector $k(X k i j) .{ }^{17}$ It takes the following shape:

$$
X_{i j}=\frac{Y_{i} Y_{j}}{Y^{w}}\left(\frac{t_{i j}}{\prod_{i} P_{j}}\right)^{1-\sigma}
$$

where $Y_{i}$ and $Y_{j}$ are the income levels of countries $i$ and $j,{ }^{18} Y^{w}$ is total world income and $\sigma>1$ is the elasticity of substitution. Precisely, $\sigma$ is the elasticity of substitution parameter between all goods in the consumption utility function. The trade cost factor, $t_{i j} \geq$ 1 , is defined as the gross bilateral cost of importing a good (one plus the tariff equivalent), so that if pi is the supply price of a good produced in country $i$, then $p_{i j}=t_{i j} p_{i}$ is the price faced by consumers in country $j . \prod_{i}$ and $P_{j}$ are country $i$ 's outward and country $j$ 's inward multilateral resistance variables, respectively. These capture the countries' average international trade barriers. The important insight of the model is that bilateral trade flows $X_{i j}$ depend on the bilateral trade barrier $t_{i j}$ relative to average international trade barriers. Therefore, trade is a product of the scale and structure of partner economies, their geographic, political and institutional proximity, and the openness of their economies to trade, and trade barriers.

As discussed, we introduce both price and non-price components of $t_{i j}$ in equation (1). We assume from equation (1) that $t_{i j}$ can be divided into several components, namely,

15 Transport is implicit in the "iceberg" model (Samuelson, 1954) - the most widely used. That model assumes that a part of the transported good is consumed in transportation.

16 It is assumed that all goods are differentiated by place of origin and that each country is specialized in the production of only one good. Therefore, the supply of each good is fixed $(\mathrm{ni}=1)$, but it allows preferences to vary across countries subject to the constraint of market clearing (CES).

17 It follows Helble and others (2007) and De (2010)

18 Aggregate sizes of import demand and export supplies of countries $i$ and $j$ respectively. These terms are used to represent the supply capability of the exporter and the demand availability of the importer for a given period of time in a static sense. 
infrastructure quality, tariff barriers, transport costs, and other border effects. Assuming a monopolistically competitive market, the term (1- $\sigma)$ should be negatively related to the volume of trade. We assume that the shipment of a container from country $i$ to country $j$ incurs three major costs: (i) inland transportation costs at exporting country $i\left(t_{i}^{I n l}\right)$; (ii) international transportation costs (port to port) between $j$ and $i\left(t_{i}^{I n l}\right)$; and (iii) inland transportation costs at importing country $j\left(t_{i}^{\text {Inl }}\right)$. Therefore, equation (1) can be rewritten as:

$$
X_{i j}=\frac{Y_{i} Y_{j}}{Y^{w}}\left(\frac{t_{j}^{I n l}+t_{i j}^{I n l}+t_{i}^{I n l}}{\Pi_{i} P_{j}}\right)^{1-\sigma}
$$

In terms of the demand side trade, the final estimable equation is therefore expressed as follows: 19

$$
\begin{aligned}
& \ln X_{i j}=\sum_{i \neq j} \alpha_{i j}+\beta_{1} \ln Y_{1}+\beta_{2} \ln T \Pi_{i}+\beta_{3} \ln T \Pi_{j}+\beta_{4} \ln \text { Port }_{i}+\beta_{5} \ln \text { Port }_{j}+ \\
& \beta_{6} \ln T_{j}^{\text {Inl }}+\beta_{7} \ln T_{i j}^{\text {Inl }}+\beta_{8} \ln T_{i}^{\text {Inl }}+\beta_{9} \ln T R_{i j}+\beta_{10} \ln E R_{j}+\beta_{11} \ln \text { Distance }+ \\
& \beta_{12} A d j+\beta_{13} \operatorname{Lan}+\beta_{13} R T A+\varepsilon_{i j}
\end{aligned}
$$

On the impact of non-price barriers to trade, we have

$$
\begin{aligned}
& \ln X_{i j}=\sum_{i \neq j} \alpha_{i j}+\beta_{1} \ln Y_{1}+\beta_{2} \ln T \Pi_{i}+\beta_{3} \ln T \Pi_{j}+\beta_{4} \ln \text { Port }_{i}+\beta_{5} \ln \text { Port }_{j}+ \\
& \beta_{6} \ln \text { Distance }+\beta_{7} A d j+\beta_{8} \text { Lan }+\beta_{9} R T A+\varepsilon_{i j}
\end{aligned}
$$

whereas, on price barriers to trade, we consider

$$
\begin{aligned}
& \ln X_{i j}=\sum_{i \neq j} \alpha_{i j}+\beta_{1} \ln Y_{1}+\beta_{2} \ln T_{j}^{I n l}+\beta_{3} \ln T_{i j}^{I n l}+\beta_{4} \ln T_{i}^{I n l}+\beta_{5} \ln T R_{i j}+ \\
& \beta_{6} \ln E R_{j}+\beta_{7} \text { InlDistance }+\beta_{8} A D j+\beta_{9} \operatorname{Lan}+\beta_{10} R T A+\varepsilon_{i j}
\end{aligned}
$$

With explicit tariff and freight rates, we revise equation (5) as follows:

$$
\begin{aligned}
& \ln X_{i j}=\sum_{i \neq j} \alpha_{i j}+\beta_{1} \ln Y_{1}+\beta_{2} \ln \left(T_{i j}+T R_{i j}\right)+\beta_{3} \ln E R_{i}+\beta_{4} \ln \text { Distance }+ \\
& \beta_{5} A d j+\beta_{6} \operatorname{Lan}+\beta_{7} R T A+\varepsilon_{i j}(6)
\end{aligned}
$$

19 This equation closely follows equation (18) of Hummels (1999). Here, export supply capability (Yj) is not included since we are considering imports in bilateral pairs. 
To understand the variability of inland and international transport costs, we use:

$$
\begin{aligned}
& \ln X_{i j}=\sum_{i \neq j} \alpha_{i j}+\beta_{1} \ln Y_{1}+\beta_{2} \ln \left(T_{j}^{\ln t}+T_{i}^{\ln l}\right)+\beta_{3} \ln T R_{i j}+\beta_{4} \ln E R_{j}+ \\
& \beta_{5} \ln \text { Distance }+\beta_{6} A d j+\beta_{7} \operatorname{Lan}+\beta_{8} R T A+\varepsilon_{i j}(7), \text { and } \\
& \ln X_{i j}=\sum_{i \neq j} \alpha_{i j}+\beta_{1} \ln Y_{1}+\beta_{2} \ln T_{i j}^{\ln t}+\beta_{3} \ln T R_{i j}+\beta_{4} \ln E R_{j}+ \\
& \beta_{5} \ln \text { Distance }+\beta_{6} A d j+\beta_{7} \text { Lan }+\beta_{8} R T A \varepsilon_{i j}
\end{aligned}
$$

where $i$ and $j$ are importing and exporting countries, respectively; $X_{i j}$ represents the bilateral import of country i from country $j$ of commodity $\mathrm{k}$; Yi denotes the total imports of country i from country $j$; TII represents the country's trade infrastructure, measured through an index; Port represents the performance of a country's port; $T_{i j}$ stands for transport costs (ad-valorem) for bilateral trade between countries $i$ and $j ; T R_{i j}$ stands for the bilateral average (ad-valorem) tariff by country $i$ for imports from country $j$; and $E R_{i}$ represents the annual average exchange rate in exporting country $i$. Distance is capital-to-capital distance between bilateral trading pairs. The parameters to be estimated are denoted by $B$, and $\varepsilon_{i j}$ is the error term.

The model considered here uses data for the years 2000 and 2008 at 4-digit HS for imports of six Asian countries, namely, China, India, Japan, Malaysia, Korea and Thailand. The model considers data at a bilateral level for all the variables for each country's individual partners. Appendix 1 presents commodity classifications. We use Maersk Sealand's freight rates to calculate inland and international transportation costs at a bilateral level (see Appendix 2). By focusing on tariffs and transport costs, we cover a major portion of trade costs. Bilateral trade, transport costs, and tariffs are taken at 4-digit HS for the years 2000 and 2008. The pooled data set comprises about 61,290 observations, 16 identical commodity groups for each year and seven countries all through. ${ }^{20}$ Appendix 3 provides the data sources, and Appendix 4 provides the note on TII and Port.

In this study, the decision to use either a fixed or random effects model was based on the Hausman $\chi^{2}$ test. ${ }^{21}$ For the fixed-effect specifications, we used the least squares dummy variable (LSDV) model, while the random-effect models are estimated using the generalized least squares (GLS) method, correcting for possible heteroscedastic errors and panel-specific serial correlation. Of the two models, the fixed-effect model (two-way) has appeared most significant. Before estimating the models, we obtained a matrix of correlation coefficients among the explanatory variables to rule out any possibility of

20 About 8.36 per cent of the total observations in the pooled framework show illogical values (missing, negative or extremely high); most such values (27 per cent) were observed in the category of fuels, mining and forest products.

21 The Hausman test examines the null hypothesis that the coefficients estimated by the efficient random effects estimator are the same as the ones estimated by the consistent fixed effects estimator. If they are the same (insignificant P-value, Prob>chi2 larger than 0.05), it is safe to use random effects (Hausman, 1978). 
multicollinearity problems. Where such problems were detected, we excluded some of the variables. $^{22}$ The following regression diagnostics were carried out for both the models: ${ }^{23}$ (i) linearity assumption between response variable and predictors was checked; (ii) statutory hypothesis tests were carried out on the parameter estimates; (iii) Ramsey tests were done to check model specification; (iv) normality of residuals was tracked through Kernel density plot; (v) all estimates were checked for heteroscedasticity through the Breusch-Pagan/Cook-Weisberg test for heteroscedasticity. Cameron and Trivedi's decomposition of IM-test was also used as an alternative; (vi) multicollinearity problems were checked by looking at partial correlations and then by using variance inflation factor (VIF);24, and (vii) the presence of serial correlation, if any, was detected through the Durbin-Watson (DW) test.

\section{Removing Barriers to Rebound Exports from Asia}

Tables 1 and 2 present estimation results for the two combined years (2000 and 2008) for two scenarios (price and non-price). We expect that the price (barrier) variables will be negatively correlated with the volume of imports, and non-price (barrier) variables will be positively related to imports, respectively. The estimated coefficients show elasticity, which is useful as an indicator of the effect of trade barriers on trade volumes. The model performs well, as most of the variables had the expected signs. Given the large cross-sectional nature of the data at 4-digit HS for the years 2000 and 2008, estimated models (Table 1) explained about 81 percent of the variations in the direction of trade flows when price variables were considered, and 85 percent when non-price variables were analyzed (Table 2).

The size of the importers market has a positive impact on the volume of imports while the barriers, price as well as non-price, impede imports. The most interesting result is the strong influence that the ad-valorem price factor $\left(\mathrm{T}_{\mathrm{ij}}+\mathrm{TR}_{\mathrm{ij}}\right)$ had on trade: $t$ he higher the price barriers between each pair of partners, the less they trade. In other words, a 10 percent rise in ad-valorem price (transport and tariff) decreases trade by 6.17 percent. Tariff and transport costs, considered separately, also influence the trade flow in the same direction, with more or less the same magnitude, and the coefficients of price variables are statistically significant. Thus, it may be said that 'price' barriers are still relatively higher than 'non-price' barriers of trade costs.

\footnotetext{
22 Appendix 5 presents partial correlations among dependent and independent variables (in natural logs).

23 These text book-type diagnostics have been done through Stata 10. We ignore placing the results due to space constraints. However, the same can be made available to interested readers on request.

24 As a rule of thumb, a variable whose VIF values are greater than 10 may merit further investigation. Tolerance, defined as $1 / \mathrm{VIF}$, is used by many researchers to check on the degree of collinearity. A tolerance value lower than 0.1 is comparable to a VIF of 10 . It means that the variable could be considered as a linear combination of other independent variables (refer to Stata 10)
} 
Table 1.

Log-linear Least Squares Estimates of Import Demand: Non-price Effects

\begin{tabular}{|c|c|c|}
\hline Variables & Coefficient & t-value \\
\hline Porti(Performance of importers' port) & $0.121 * *$ & 3.71 \\
\hline Port;(Performance of exporters' port) & $0.410 * * *$ & 13.24 \\
\hline TII $\mathrm{i}_{\mathrm{i}}$ Trade infrastructure of importer) & $0.391 * * *$ & 17.62 \\
\hline TIIj(Trade infrastructure of exporter) & $0.579 * * *$ & 32.13 \\
\hline $\mathrm{Y}_{\mathrm{j}}($ Importer market size $)$ & $0.348 * * *$ & 53.70 \\
\hline Distance $_{\mathrm{ij}}$ & $-0.477 * * *$ & 17.237 \\
\hline Adjacency dummy & $0.337 * * *$ & 14.56 \\
\hline Language dummy & $0.210 * * *$ & 18.98 \\
\hline RTA dummy & $0.193 * *$ & 11.02 \\
\hline Number of observations & \multicolumn{2}{|c|}{61,290} \\
\hline Adj. $\mathrm{R}^{2}$ & \multicolumn{2}{|c|}{0.810} \\
\hline
\end{tabular}

Notes: The dependent variable is a log of import of goods (at 4-digit HS) in a bilateral pair. The cross-section was pooled for the years 2000 and 2008. Country fixed effect is included in the model.

*significant at the 10 per cent level;

** significant at the 5 per cent level;

$* * *$ significant at the 1 per cent level. 
price and non-price barriers revisited

Table 2.

Log-linear least squares estimates of import demand: price effects

\begin{tabular}{|c|c|c|c|c|}
\hline \multirow{2}{*}{ Variables } & \multicolumn{2}{|c|}{ Model 1} & \multicolumn{2}{|c|}{ Model 2} \\
\hline & Coefficient & t-value & Coefficient & t-value \\
\hline $\mathrm{TR}_{\mathrm{ij}}($ Tariff $)$ & & & $-0.276^{* * *}$ & -16.190 \\
\hline $\mathrm{T}_{\mathrm{ij}}+\mathrm{TR}_{\mathrm{ij}}$ (Transport+Tariff) & $-0.617 * * *$ & -24.390 & & \\
\hline $\begin{array}{l}\mathrm{T}_{\mathrm{ij}}^{\text {Int }}+\mathrm{T}_{\mathrm{i}}^{\mathrm{Inl}} \text { (Internationaltransport+ } \\
\text { Inlandtransportofimporter) }\end{array}$ & & & $-0.225 * * *$ & -32.920 \\
\hline $\mathrm{ER}_{\mathrm{j}}$ (Exchangerate) & $0.010^{*}$ & 2.360 & 0.005 & 1.680 \\
\hline $\mathrm{Y}_{\mathrm{j}}($ Importermarketsize $)$ & $0.417 * * *$ & 576.090 & $0.484 * * *$ & 396.870 \\
\hline Distance $_{\mathrm{ij}}$ & $-0.601 * * *$ & -12.883 & $-0.710 * * *$ & -14.128 \\
\hline Adjacency dummy & $0.235^{* * *}$ & 10.570 & $0.277 * * *$ & 10.490 \\
\hline Language dummy & $0.487 * * *$ & 11.451 & $0.510 * * *$ & 10.459 \\
\hline RTA dummy & $0.302 * *$ & 5.432 & $0.343^{* *}$ & 5.672 \\
\hline Number of observations & \multicolumn{2}{|c|}{61,290} & \multicolumn{2}{|c|}{61,290} \\
\hline Adj. $\mathrm{R}^{2}$ & \multicolumn{2}{|c|}{0.851} & \multicolumn{2}{|c|}{0.851} \\
\hline \multirow{2}{*}{ Variables } & \multicolumn{2}{|c|}{ Model 3} & \multicolumn{2}{|c|}{ Model 4} \\
\hline & Coefficient & t-value & Coefficient & t-value \\
\hline $\mathrm{T}_{\mathrm{ij}}$ (Transport) & & & $-0.075^{* *}$ & 4.840 \\
\hline $\mathrm{TR}_{\mathrm{ij}}($ Tariff) & $-0.251^{* * *}$ & -15.550 & $-0.240 * * *$ & -15.120 \\
\hline $\mathrm{T}_{\mathrm{ij}}^{\text {Int }}$ (International transport) & $0.053^{* *}$ & 4.790 & & \\
\hline ER $_{\mathrm{j}}$ (Exchange rate) & $0.011^{*}$ & 2.820 & $0.011 *$ & 2.800 \\
\hline $\mathrm{Y}_{\mathrm{j}}($ Importer market size $)$ & $0.485 * * *$ & 362.820 & $0.486^{* * *}$ & 361.320 \\
\hline Distance $_{\mathrm{ij}}$ & $-0.573 * * *$ & 16.809 & $-0.519 * * *$ & -15.187 \\
\hline Adjacency dummy & $0.241 * * *$ & 9.000 & $0.235^{* * *}$ & 8.900 \\
\hline Language dummy & $0.530 * * *$ & 11.091 & $0.558 * * *$ & 10.856 \\
\hline RTA dummy & $0.337^{* *}$ & 5.431 & $0.301 * *$ & 5.80 \\
\hline Number of observations & \multicolumn{2}{|c|}{61,290} & \multicolumn{2}{|c|}{61,290} \\
\hline Adj. $\mathrm{R}^{2}$ & \multicolumn{2}{|c|}{0.853} & \multicolumn{2}{|c|}{0.850} \\
\hline
\end{tabular}

Notes: Dependent variable is log of import of goods (at 4-digit HS) in bilateral pair. Cross-section pooled for the years 2000 and 2008. Country fixed effect included in the model.

* significant at the 10 percent level;

**significant at the 5 per cent level;

$* * *$ significant at the 1 per cent level. 
International transport cost, when considered separately, had a positive sign and was significant at the 5 percent level. This also suggests that there are huge infrastructure bottlenecks in Asia that call for urgent measures for infrastructure improvement. Therefore, trade facilitation has a strong role to play in reducing trade costs and raising competitiveness in India, and possibly other South Asian countries.

Contrary to expectations, in all models, the exchange rate in the exporting appeared with a positive coefficient. Possible explanations include: (a) Currency depreciation had little effect on aggregate trade flow during the period of our study; or (b) there was appreciation against the United States dollar. In fact, the US dollar weakened in the crisis period. In all models, distance had the correct sign, and was statistically significant. The adjacency, language and RTA dummies, which are proxies of indirectly measured barriers, have positive signs in all the models, which indicate that sharing a border, speaking a common language, and free trade (regional and bilateral) environment do matter in trade in India.

In the case of non-price variables, the estimated results indicate that the trading infrastructure of exporting countries is much more important than that of importing countries; this coefficient is statistically significant at the 1 percent level. Similarly, the port performance of exporting countries has a comparatively higher positive effect on trade flow than does the port performance of importing countries. The adjacency, language and RTA dummies have the expected signs and are also significant.

The direction of the influence of price and non-price factors on trade flow has been researched extensively. However, the combined effect of explicit barriers, such as transport and tariffs, on trade was unknown. As mentioned above, estimated coefficients indicated that a 10 percent increase in price barriers such as tariffs and transport costs would lower Asian aggregate trade by 6 percent. We would expect an analysis of disaggregated data to reveal variations in the effects of barriers.

This is also not to deny that models also suffer from endogeneity as highly correlated exogenous variables are used in some cases in the gravity equations. The relationships described above cannot be interpreted as causal until we rule out the possibility of endogeneity. To address this problem, we may use a dynamic GMM estimator (systemGMM) to analyze changes across countries and over time. The estimator also effectively deals with reverse causality by using a set of instruments for the endogenous variables, and includes the lagged dependent variable to account for the persistence of the infrastructure indicator. Alternative estimations such as the maximum likelihood estimation (MLE) and frontier maximum likelihood estimation (FMLE) may also be used in order to check the relative robustness of the models. These are some suggestions for future research agendas. 


\section{Conclusions}

Over the past decades of globalization, economies in Asia have grown rapidly until the financial crisis appeared in mid 2007. This acceleration of growth, in which international trade has played an important role, has helped Asian economies make impressive strides in economic development. The globalization process has resulted in an increase in international trade in goods and services in both extensive and intensive margins in Asia. Asia has experienced a sharp increase in merchandise trade and has been showing greater trade interdependence on a large variety of goods, particularly in intermediate and capital goods. However, rising trade costs (attributable to higher tariffs and freight rates) continued to impede trade in Asia. The main conclusion of this paper is that 'price' barriers are still more important than 'non-price' barriers, ceteris paribus, in enhancing Asia's trade. The higher the price barriers between countries in a pair, the less they traded. In other words, a 10 percent increase in the ad-valorem price (transport and tariff) lowered trade by 6 percent. Tariff and transport costs, each considered separately, also influence the trade flow in the same direction, to more or less the same extent. The analysis carried out in this study provides sufficient evidence to ascertain that variations in tariffs and transport costs have significant influence on regional trade flows in Asia. The findings of this study indicate huge domestic infrastructure bottlenecks in countries in Asia that call for immediate attention in order to enhance trade flows in Asia. Therefore, infrastructure has an important role to play in reducing trade costs in Asia.

Given these broad findings, we can say that with the rise of regionalism (and also bilateralism) in Asia, any attempt towards regional demand driven growth rebalancing of the region holds high promise only if accompanied by initiatives that help improve trade efficiency and reduce trade costs. Reductions in transportation costs should be a priority in any new policy for Asia's infrastructure development, since a decrease in transportation costs, as an outcome of improved infrastructure, will stimulate trade. The challenge for Asian countries is thus to identify improvements in logistics services and related infrastructure that can be achieved in the short-to-medium term and that would have a significant impact on the competitiveness of Asian countries.

\section{References}

Anderson, J.E., and E. van Wincoop. 2002. Borders, trade and welfare, in . S. Collins and D. Rodrik (eds.) Brookings Trade Forum 2001 (Washington D.C., Brookings Institution) pp. 207-244.

Anderson, J.E., and E. van Wincoop. 2004. Trade costs, Journal of Economic Literature, vol. 42, No. 3, pp. 691-751.

Asia Pacific Economic Cooperation (APEC). 2002. Measuring the Impact of APEC Trade 
Facilitation on APEC Economies: A CGE Analysis (Singapore).

Asian Development Bank (ADB). 2006. Asian Development Outlook 2006: Routes for Asia's Trade (Hong Kong).

Asian Development Bank (ADB) - Asian Development Bank Institute (ADBI). 2009, Infrastructure for a Seamless Asia, (Manila and Tokyo).

Baier, S.L., and J.F. Bergstrand. 2001. The growth of world trade: tariffs, transport costs, and income similarity, Journal of International Economics, vol. 53, pp. 1-27.

Balasaa, B. 1961. The Theory of Economic Integration (Homewood, Richard D. Irwin).

Bergstrand, J.H. 1985. The gravity equation in international trade: some microeconomic foundations and empirical evidence, Review of Economics and Statistics, vol. 67, pp. 474-81.

Bergstrand, J.H. 1989. The generalized gravity equation, monopolistic competition, and the factor-proportions theory in international trade, Review of Economics and Statistics, vol. 71, pp. 143-53.

Bougheas, S.. P. Demetriades, Edgar Morgenroth. 1999. Infrastructure, transport costs, and trade, Journal of International Economics, vol. 47, No. 1, pp. 169-189.

Brooks, D. 2008-a. Linking Asia's trade, logistics, and infrastructure, ADBI Working Paper 128, (Tokyo, Asian Development Bank Institute (ADBI)).

. 2008-b. Regional cooperation, Infrastructure and Trade Costs, ADBI Working Paper 123, (Tokyo, Asian Development Bank Institute (ADBI)).

. 2009. Infrastructure's Role in Lowering Asia's Trade Costs in D. Brooks and D. Hummels (eds.), Infrastructure and Trade Costs in Asia (Cheltenham, Edward Elgar).

Brooks, D., and D. Hummels. (eds.). 2009. Infrastructure's Role in Lowering Asia's Trade Costs: Building for Trade (Northampton, Edward Elgar).

Brooks, D., and J. Menon (eds.). 2008. Infrastructure and Trade in Asia (Cheltenham. Edward Elgar).

Cernat, L. 2001. Assessing Regional Trading Arrangements: Are South-South RTAs More Trade Diverting?, Policy Issues in International Trade and Commodities Study Series No. 16 (United Nations publication, Sales No. E.01.II.D).

Clark, X., D. David and A. Micco. 2004. Port efficiency, maritime transport costs and bilateral trade, Working Paper 10353, NBER, Cambridge.

Davis, D. 1998. The home market effect, trade and industrial structure, American Economic Review, vol. 88, No. 5, pp. 1264-1276

De, P. 2005. Affect of Transaction Costs on International Integration in the Asian Economic Community, in Asian Development Bank (ed.), Asian Economic Cooperation and Integration: Progress, Prospects, Challenges (Manila, ADB).

. 2006-a. Regional trade in Northeast Asia: Why do trade costs matter?, CESifo Working Paper No. 1809 (Munich, Munich Society for the Promotion of Economic Research (CESifo)). 
. 2006-b. Trade, infrastructure and transaction costs: the imperatives for Asian economic cooperation, Journal of Economic Integration, vol. 21, No. 4, pp. 708-735.

2007. Impact of trade costs on trade: empirical evidence from Asian countries, Asia-Pacific Research and Training Network on Trade (ARTNeT) Working Paper No. 27 (Bangkok, ESCAP).

. 2008-a. Trade costs and infrastructure: analysis of the effects of trade impediments in Asia, Journal of Integration and Trade, vol. 12, No. 28, pp. 241-266.

. 2008-b. Empirical estimates of trade costs for Asia, in D. Brooks and J. Menon (eds.), Infrastructure and Trade in Asia, (Cheltenham, Edward Elgar).

. 2008-c. Realising the gains from full regional connectivity in South Asia: the transport costs dimension, Man and Development, vol. 30, No. 1, pp. 27-44.

. 2009-a. Empirical estimates of transportation costs: options for enhancing Asia's trade, in D. Brooks and D. Hummels (eds.), Infrastructure and Trade Costs in Asia (Cheltenham, Edward Elgar).

. 2009-b. Trade transportation costs in South Asia: an empirical investigation, in D. Brooks and D. Hummels, (eds.), Infrastructure and Trade Costs in Asia, (Cheltenham, Edward Elgar).

. 2009-c. Enhancing Asia's trade: transport costs matter, in UNESCAP (ed.), Impact of Trade Facilitation on Export Competitiveness: A Regional Perspective, United Nations, Bangkok.

2010. Global economic and financial crisis: India's trade potential and prospects, and Implications for Asian Regional Integration, Journal of Economic Integration, Vol. 25, No. 1, pp. 32-68.

Deardorff, A. 1998. Determinants of bilateral trade: does gravity work in a neo-classical world? in J. Frankel (ed.), Regionalization of the World Economy (Chicago, University of Chicago Press).

Dixit, A., and J. Stiglitz. 1977. Monopolistic competition and optimum product diversity, American Economic Review, vol. 67, pp. 297-308.

Djankov, S., C. Freund and C.S. Pham. 2006. Trading on time, Working Paper, (Washington, D.C, World Bank).

Duval, Y. 2007. Trade facilitation beyond the Doha Round of Negotiation, Asia-Pacific Research and Training Network on Trade (ARTNeT) Working Paper No. 50, (Bangkok, ESCAP).

Duval, Y., and C. Utokhtam. 2009. Behind the Border Trade Facilitation in Asia-Pacific: Cost of Trade, Credit Information, Contract Enforcement and Regulatory Coherence, Trade and Investment Division Staff Working Paper Series, No. 02/2009. ESCAP, United Nations.

Fink, C., A. Mattoo and I.C. Neagu. 2002. Trade in international maritime services: how 
much does policy matter?, The World Bank Economic Review, vol. 16, pp. 451-479.

Francois, J., and M. Manchin. 2006. Institutional Quality, Infrastructure, and the Propensity to Export (London, CEPR).

Francois, J., H. van Meijland and F. van Tongeren. 2005. Trade liberalization in the Doha Development Round, Economic Policy, vol. 20, No. 42, pp. 349-391.

Government of India. 2010. Economic Survey 2009-2010, Ministry of Finance, New Delhi.

Hiratsuka, D. (ed.). 2006. East Asia's De Facto Economic Integration, Institute of Developing Economies (IDE-JETRO) Series (Basingstoke, Palgrave Macmillan).

Hummels, D and A. Skiba. 2004. Shipping the good apples out? An empirical confirmation of the Alchian-Allen conjecture, Journal of Political Economy, vol. 112, No. 6, pp. 1384-1402.

Hummels, D. 1999. Toward a geography of trade costs, Working Paper (Chicago, University of Chicago).

. 2000. Time as trade barrier, Global Trade Analysis Project (GTAP) Working Paper Working Paper (West Lafayette, Purdue University).

. 2007. Transportation costs and international trade in the second era of globalization, Journal of Economic Perspectives, vol. 21, No. 3, pp. 131-154.

. 2009. Trends in Asian trade: implications for transport infrastructure and trade costs, in D. Brooks and D. Hummels (eds.), Infrastructure and Trade Costs in Asia (Cheltenham, Edward Elgar).

International Monetary Fund (IMF). 2010-a. World Economic Outlook Update, A Policy-Driven, Multispeed Recovery, Tuesday, January 26, 2010.

International Monetary Fund. 2010-b. Direction of Trade Statistics On-line Database, (Washington D.C.).

John S. Wilson, Catherine Mann, Yuen Pau Woo, Nizar Assanie, Inbom Choi. 2002. Trade Facilitation: A Development Perspective in the Asia Pacific Region, (Singapore, APEC Secretariat).

Kawai, M. 2009. Reform of the International Financial Architecture: An Asian Perspective, ADBI Working Paper 167 (Tokyo, Asian Development Bank Institute (ADBI)).

Khan, H. 2008. Regional co-operation, governance, soft infrastructure and trading costs, in Brooks, D. and J. Menon (eds.), Infrastructure and Trade in Asia (Cheltenham, Edward Elgar).

Krugman, P. 1980. Scale economies, product differentiation, and the pattern of trade, American Economic Review, vol. 70, pp. 950-959.

. 1991. Increasing returns and economic geography, Journal of Political Economy, vol. 99, pp. 483-499.

Krugman, P., and A.J. Venables. 1990. Integration and the competitiveness of peripheral industry, in C. Bliss and J. Braga de Macedo (eds.), Unity with Diversity in the 
European Economy, (Cambridge University Press), pp. 56-75.

Kuroiwa, I. 2006. Production networks and spatial linkages in East Asia, in Hiratsuka (ed.)

East Asia's de Facto Economic Integration, Institute of Developing Economies (IDE-JETRO) Series (Basingstoke, Palgrave Macmillan).

Limão, N. and A.J. Venables. 2001. Infrastructure, geographical disadvantage, transport costs, and trade, The World Bank Economic Review, vol. 15, pp. 451-479.

Maersk Sealand. 2009. Scale of Rates, (Copenhagen, Denmark)

Nordås, H.K and Piermartini R. 2004. Infrastructure and trade, Staff Working Paper ERSD-2004-04, Economic Research and Statistics Division (Geneva, World Trade Organization).

Obstfeld, M, and Rogoff, K. 2000. The six major puzzles in international macroeconomics: is there a common cause?, in B.S. Bernanke and K. Rogoff (eds.) NBER Macroeconomics Annual 2000 (Cambridge, MIT Press) pp. 339-390.

. 2005. The Costs and Benefits of Trade Facilitation (Paris).

Park, Y. C. 2009. The Global Economic Crisis and Rebalancing Growth in East Asia, ADBI Policy Brief 31, (Tokyo, Asian Development Bank Institute (ADBI)).

Redding S., and A.J. Venables. 2004. Economic geography and international inequality, Journal of International Economics, vol. 62, No. 1, pp. 53-82.

Samuelson, P.A. 1954. The transfer problem and transport costs: the terms of trade when impediments are absent, Economic Journal, vol. 62, pp. 278-304.

Steininger, K.W. 2001. International Trade and Transport (Cheltenham, Edward Elgar).

United Nations Economic and Social Commission for Asia and the Pacific (UNESCAP). 2009. Asia-Pacific Trade and Investment Report 2009, (Bangkok)

Walkenhorst, Peter. 2003. Quantitative Assessment of the Benefits of Trade Facilitation (Paris, Organization for Economic Cooperation and Development).

Walkenhorst, Peter and Tadashi Yasui. 2003. Quantitative assessment of the benefits of trade facilitation (TD/TC/WP.2003.31/FINAL) (OECD).

Wilson, J.S., C.L. Mann and T. Otsuki. 2003. Trade facilitation and economic development: a new approach to quantifying the impact, The World Bank Economic Review, vol. 17, No. 3, pp. 367-389.

World Bank. 2001. Global Economic Prospects and the Developing Countries. 2002.: Making Trade Work for the Poor (Washington, D.C.). .2010. World Development Indicators. 2009. Online Database, (Washington, D.C.).

World Trade Organization (WTO) and International Trade Centre UNCTAD/WTO (ICT). 2009. World Tariff Profiles. 2009. (Geneva)

Yeaple, S. and S.S. Golub. 2002. International Productivity Differences, Infrastructure and Comparative Advantage, (Pennsylvania, University of Pennsylvania). 
Appendix 1. Classification of commodity groups

\begin{tabular}{|c|c|c|}
\hline & $\begin{array}{c}\text { Corresponding } \\
\text { 2/4 -digit HS (2002) }\end{array}$ & Remarks \\
\hline Agriculture products & $01-24,50-53$ & \multirow{2}{*}{$\begin{array}{l}\text { Taken at 4-digit HS } \\
\text { excluding HS } 01 \text { and HS } 06\end{array}$} \\
\hline Food & $16-23$ & \\
\hline Fuels, mining and forest products & $25-27,44$ & $\begin{array}{l}\text { Taken at 4-digit HS, } \\
\text { excluding HS } 45\end{array}$ \\
\hline Manufactures & $\begin{array}{l}28-43,45-49 \\
54-70,72-92,94-96\end{array}$ & $\begin{array}{l}\text { Taken at 4-digit HS, excluding } \\
\text { HS 44, } 50-53,71,93\end{array}$ \\
\hline Chemical & $28-36,38$ & \multirow{5}{*}{$\begin{array}{l}\text { Taken at 4-digit HS, } \\
\text { excluding HS } 37\end{array}$} \\
\hline Pharmaceuticals & 30 & \\
\hline Rubber and plastics & $39-40$ & \\
\hline Leather & $41-43,64$ & \\
\hline Paper and pulp & $47-48$ & \\
\hline Textile and clothing & $54-63$ & \multirow{3}{*}{$\begin{array}{l}\text { Taken at 4-digit HS, } \\
\text { excluding HS } 64 \text { - 67, } 71\end{array}$} \\
\hline Iron and steel & $72-73$ & \\
\hline Metal & $68-70,74-81$ & \\
\hline Machinery and mechanical appliances & $82-84$ & $\begin{array}{l}\text { Taken at 4-digit HS, excluding } \\
\text { HS } 8415,8418,8471,8473\end{array}$ \\
\hline Electrical and electronics & $85,90,91,92,95$ & \multirow{5}{*}{$\begin{array}{l}\text { Taken at 4-digit HS, including } \\
\text { HS 8415, 8418, 8471, } 8473\end{array}$} \\
\hline Office and telecom equipment & $8517-8548$ & \\
\hline Electronic integrated circuits & 8542 & \\
\hline Transport equipment & $86-89$ & \\
\hline Agriculture products & 87 & \\
\hline
\end{tabular}

Appendix 2. Components of international transport cost (US\$ / Twenty-foot equivalent unit)

\begin{tabular}{l|c|c|c|c}
\hline \multirow{2}{*}{} & \multicolumn{2}{|c|}{ Terminal handling charges $^{\mathbf{a}}$} & \multicolumn{2}{c}{ Ocean freight charges $^{\mathbf{b}}$} \\
\cline { 2 - 5 } & $\mathbf{2 0 0 0}$ & $\mathbf{2 0 0 8}$ & $\mathbf{2 0 0 0}$ & $\mathbf{2 0 0 8}$ \\
\hline \hline China & 223 & 537 & 338 & 570 \\
\hline India & 374 & 820 & 729 & 1389 \\
\hline Indonesia & 235 & 466 & 416 & 643 \\
\hline Japan & 339 & 526 & 556 & 720 \\
\hline Malaysia & 245 & 401 & 409 & 503 \\
\hline Korea & 238 & 332 & 456 & 531 \\
\hline Thailand & 184 & 324 & 310 & 389
\end{tabular}

Note: a Average (weighted) over all commodities. b Other than terminal handling charges.

Source: Calculated based on date from Maersk Sealand (2009). 


\section{Appendix 3. Sources of data}

\begin{tabular}{l|l}
\hline \multicolumn{1}{c|}{ Particular } & \multicolumn{1}{c}{ Source } \\
\hline \hline & \begin{tabular}{l}
\multicolumn{1}{c}{ United Nations Commodity Trade Statistics } \\
Database \\
International Monetary Fund, Direction of \\
Trade Statistics Database
\end{tabular} \\
\hline & $\begin{array}{l}\text { World Bank, World Integrated Trade Solution; } \\
\text { United Nations Conference on Trade and } \\
\text { Development, Trade Analysis and Information } \\
\text { System }\end{array}$ \\
\hline $\begin{array}{l}\text { Gross domestic product, gross domestic product } \\
\text { per capita, surface area, population }\end{array}$ & $\begin{array}{l}\text { World Bank, World Development Indicators } \\
\text { 2009 }\end{array}$ \\
\hline $\begin{array}{l}\text { Infrastructure variables: (a) railway length; (b) } \\
\text { road length; (c) air transport freight; (d) air } \\
\text { transport passengers carried; (e) aircraft } \\
\text { departures; (f) container traffic; (g) fixed-line } \\
\text { and mobile phone subscribers; (h) Internet } \\
\text { users; and (i) electric power consumption }\end{array}$ & $\begin{array}{l}\text { World Bank, World Development Indicators } \\
\text { CIA International }\end{array}$ \\
\hline \begin{tabular}{l} 
Freight \\
\hline
\end{tabular} & Asia Infrastructure Database Version 1.0 \\
\hline
\end{tabular}

\section{Appendix 4. Trade infrastructure index (TII) and port}

To assess country characteristics and domestic (inland) transport costs, infrastructure measures the country's ability to enhance the merchandise trade-were the focus. Infrastructure is treated here as a proxy for those costs, because it is responsible for the movement of goods across and within countries. We have used Principal Component Analysis (PCA) for indexing the trade infrastructure. While indexing the infrastructure stocks of the countries, the following nine variables, which are directly involved in moving merchandise between countries, were considered: (a) railway length density (km per 1,000 $\mathrm{km}^{2}$ of surface area); (b) road length density (km per 1,000 $\mathrm{km}^{2}$ of surface area); (c) air transport freight (million tons per $\mathrm{km}$ ); (d) air transport, passengers carried (percentage of population); (e) aircraft departures (percentage of population); (f) country's percentage share in world fleet; $(\mathrm{g})$ container port traffic (twenty-foot equivalent units per terminal); (h) fixed-line and mobile phone subscribers (per 1,000 people); and (i) electric power consumption (kwh per capita). 
Estimated weights : Principal component analysis

\begin{tabular}{l|c|c}
\hline \multirow{2}{*}{ Infrastructure Indicator } & \multicolumn{2}{c}{ Factor loadings (1) } \\
\cline { 2 - 3 } & $\mathbf{2 0 0 0}$ & $\mathbf{2 0 0 8}$ \\
\hline \hline Air transport freight (million tons per km) & 0.73 & 0.78 \\
\hline Air transport, passengers carried (percentage of population) & 0.80 & 0.82 \\
\hline Aircraft departures (percentage of population) & 0.80 & 0.96 \\
\hline Country's percentage share in world fleet & 0.31 & 0.36 \\
\hline Container port traffic (TEUs per terminal) & 0.45 & 0.53 \\
\hline Electric power consumption (kwh per capita) & 0.77 & 0.97 \\
\hline Fixed-line and mobile phone subscribers (per 1 000 people) & 0.89 & 0.91 \\
\hline Railway length density (km per 1000 sq. km of surface area) & 0.83 & 0.94 \\
\hline Road length density (km per 1000 sq. km of surface area) & 0.84 & 0.89 \\
\hline Expl.Var (\% of total) & 0.64 & 0.67 \\
\hline
\end{tabular}

Note: Factor loadings (Unrotated)

Estimated trade infrastructure index, 2000 and 2008

\begin{tabular}{c|c|c}
\hline & $\mathbf{2 0 0 0}$ & $\mathbf{2 0 0 8}$ \\
\hline \hline China & 1.65 & 1.88 \\
\hline India & 0.49 & 0.57 \\
\hline Indonesia & 0.45 & 0.48 \\
\hline Japan & 4.02 & 4.08 \\
\hline Malaysia & 1.69 & 1.73 \\
\hline Korea & 3.11 & 3.23 \\
\hline Thailand & 0.84 & 0.93 \\
\hline
\end{tabular}


Performance of ports: number of containers (TEUs) handled per hour, 2000 and 2008

\begin{tabular}{c|c|c}
\hline & $\mathbf{2 0 0 0}$ & $\mathbf{2 0 0 8}$ \\
\hline \hline China & 21 & 41 \\
\hline India & 12 & 29 \\
\hline Indonesia & 11 & 21 \\
\hline Japan & 27 & 37 \\
\hline Malaysia & 39 & 44 \\
\hline Korea & 31 & 45 \\
\hline Thailand & 12 & 29 \\
\hline
\end{tabular}

Note: Average of country's top three largest container ports.

Source: Calculated based on International Association of Ports and Harbours.

\section{Appendix 5. Pair-wise correlation coefficients}

\begin{tabular}{|c|c|c|c|c|c|c|c|c|c|c|c|}
\hline & $\mathbf{X}_{\mathrm{ij}}$ & $Y_{i}$ & $\mathbf{T R}_{\mathrm{ij}}$ & $T_{i j}^{\text {Int }}$ & $T_{i j}$ & $T_{i}^{\text {Inl }}$ & $\mathbf{E R}_{\mathbf{j}}$ & Port $_{i}$ & Port $_{j}$ & $\mathrm{TII}_{\mathbf{i}}$ & TII $_{j}$ \\
\hline$X_{i j}$ & 1 & & & & & & & & & & \\
\hline $\mathrm{Y}_{\mathrm{i}}$ & $0.726^{*}$ & 1 & & & & & & & & & \\
\hline $\mathrm{TR}_{\mathrm{ij}}$ & $-0.527^{*}$ & $-0.546^{*}$ & 1 & & & & & & & & \\
\hline $\mathrm{T}_{\mathrm{ij}}^{\text {Int }}$ & $0.361^{*}$ & $0.405^{*}$ & $-0.151^{*}$ & 1 & & & & & & & \\
\hline $\mathrm{T}_{\mathrm{ij}}$ & $-0.460^{*}$ & $0.411^{*}$ & $-0.272^{*}$ & $0.708^{*}$ & 1 & & & & & & \\
\hline $\mathrm{T}_{\mathrm{i}}^{\mathrm{Inl}}$ & $-0.062^{*}$ & $-0.011^{*}$ & -0.003 & $0.350^{*}$ & $0.414^{*}$ & 1 & & & & & \\
\hline $\mathrm{ER}_{\mathrm{j}}$ & $0.022^{*}$ & $0.021^{*}$ & $0.03^{*}$ & $0.021^{*}$ & $0.005^{*}$ & $-0.037^{*}$ & 1 & & & & \\
\hline Port $_{i}$ & $-0.681^{*}$ & $-0.706^{*}$ & $0.550^{*}$ & $-0.411^{*}$ & $-0.311^{*}$ & $0.030^{*}$ & $0.021^{*}$ & 1 & & & \\
\hline Port $_{j}$ & $-0.400^{*}$ & $-0.451^{*}$ & $0.295^{*}$ & $-0.313^{*}$ & $-0.318^{*}$ & $-0.011^{*}$ & $-0.422^{*}$ & $0.430^{*}$ & 1 & & \\
\hline $\mathrm{TII}_{\mathrm{i}}$ & $-0.619^{*}$ & $-0.715^{*}$ & $0.550^{*}$ & $-0.426^{*}$ & $-0.408^{*}$ & $0.052^{*}$ & $-0.021^{*}$ & $0.970^{*}$ & $0.453^{*}$ & 1 & \\
\hline $\mathrm{TII}_{\mathrm{j}}$ & $-0.041^{*}$ & 0.001 & $0.020^{*}$ & $-0.135^{*}$ & $-0.078^{*}$ & $-0.099 *$ & $-0.173^{*}$ & -0.000 & $0.701^{*}$ & 0.006 & 1 \\
\hline
\end{tabular}

Note: Taken in log scale. * significant at the 5 per cent level 